\title{
Correlation of ultrasonic measured ribeye area and fat thickness to the certain traits measured on slaughtered bulls (Short Communication)
}

\author{
MÁRTONTÖRÖK, J. PÉTER POLGÁR, GYULA KOCSI, VALÉRIA FARKAS and FERENC SZABÓ \\ Georgikon Faculty of Agriculture, University of Pannonia, Keszthely, Hungary
}

\section{Abstract}

The aim of this study was to test accuracy of measurements done by Falco 100 (Pie Medical) ultrasonic equipment. 10 Angus, 10 Hungarian Simmental, 10 Limousin and 10 Charolais fattening bulls were measured at the feedlot just before slaughtering. Fat thickness at the rump (P8) and ribeye area (REA) were realized from each animal. After slaughtering, the data of slaughter and carcass weights were collected and carcasses were judged on the base of EUROP system. The database was examined by SPSS 9.0 for Windows. Average liveweight of Angus was $645 \pm 41.5 \mathrm{~kg}$, of Hungarian Simmental was $676 \pm 41.8 \mathrm{~kg}$, of Limousin was $655 \pm 50.8 \mathrm{~kg}$ and of Charolais was $694 \pm 42.3 \mathrm{~kg}$ at the measurement. REA measured with ultrasound was $102.9 \pm 8.9 \mathrm{~cm}^{2}, 102.7 \pm 10.4 \mathrm{~cm}^{2}$, $111.2 \pm 9.6 \mathrm{~cm}^{2}$ and $106.4 \pm 9.5 \mathrm{~cm}^{2}$, respectively. $P 8$ was $1.05 \pm 0.28 \mathrm{~cm}, 0.62 \pm 0.13 \mathrm{~cm}$, $0.62 \pm 0.09$ and $0.61 \pm 0.18 \mathrm{~cm}$, respectively. Correlation between ultrasonic and carcass REA in case of mentioned breeds was $0.74,0.74,0.94$ and 0.80 . Correlation between P8 and EUROP fat score was $0.51,0.73,0.56$ and 0.28 , respectively. Overall correlation between ultrasonic and carcass REA was $0.83(P \leq 0.01)$, and between P8 and EUROP fat score was $0.69(P \leq 0.01)$.

Keywords: bulls, ultrasound, accuracy, ribeye area, fat thickness

\section{Zusammenfassung}

\section{Beziehungen zwischen Ultraschallmessdaten der Rückenmuskelfläche und Rücken- fettdicke zu Schlachtergebnissen von Mastbullen (Kurzmitteilung)}

Das Ziel der Untersuchung war die Prüfung der Genauigkeit des Ultraschallgerätes Falco 100 (Pie Medical). Unmittelbar vor der Schlachtung von je 10 Mastbullen der Rassen Angus, Ungarisches Fleckvieh, Limousin und Charolais erfolgte die Ultraschallmessung der Rückenfettdicke (P8) sowie der Rückenmuskelfläche (REA). Nach der Schlachtung wurden die Schlachtausbeute, das Hälftengewicht, die EUROP Fleischigkeits- und Fettgewebeklasse sowie die am Schlachtkörper dem Ultraschall vergleichbaren Messdaten festgestellt und mit dem Programmpaket SPSS 9.0 für Windows ausgewertet.

Zum Zeitpunkt der Messung und Schlachtung betrugen die Lebendgewichte der Bullen: Angus $=645 \pm 41,5 \mathrm{~kg}$, Ungarisches Fleckvieh $=676 \pm 41,8 \mathrm{~kg}$, Limousin $=655 \pm 50,8 \mathrm{~kg}$ und Charolais $=694 \pm 42,3 \mathrm{~kg}$. In der genannten Reihenfolge der Rassen wurden folgende Ultraschallmesswerte für die Rückenmuskelfläche $102,9 \pm 8,9 \mathrm{~cm}^{2}, 102,7 \pm 10,4 \mathrm{~cm}^{2}$, $111,2 \pm 9,6 \mathrm{~cm}^{2}$ und $106,4 \pm 9,5 \mathrm{~cm}^{2}$ ermittelt bzw. für die Rückenfettdicke von 1,05 $\pm 0,28 \mathrm{~cm}$, 
$0,62 \pm 0,13 \mathrm{~cm}, 0,62 \pm 0,09 \mathrm{~cm}$ und $0,61 \pm 0,18$. Zwischen den Ultraschallmesswerten der REA und der am Schlachtkörper gemessenen REA ergaben sich für die vier Bullengruppen Korrelationskoeffizienten von $r=0,74,0,74,0,94$ und 0,80. Die Werte für die Beziehungen zwischen der mittels Ultraschall gemessenen P8 und den EUROP Fettgewebeklassen betrug $r=0,51,0,73,0,56$ und 0,28. Die Durchschnittswerte der Korrelationskoeffizienten für die Tiere aller Rassen betrugen für die REA $r=0,83(P \leq 0,01)$ und die Beziehung P8 zu den EUROP Fettgewebeklassen $r=0,69(P \leq 0,01)$.

Schlüsselwörter: Mastbullen, Ultraschallmessung, Genauigkeit, Rückenmuskelfläche, Rückenfettdicke

\section{Introduction}

New methods such as ultrasonic technics for the measurement of the body composition in vivo (or post mortem) need to be evaluated before routine use in livestock research or performance testing (SCHOLZ \& FÖRSTER 2006).

KALLWEIT et al. (1994) reported that magnetic resonance imaging (MRI) is an excellent non invasive method to study morphological structures in live animals and these estimation results can serve as a reference for other evaluation methods. However, ultrasound is easier to use in daily practice and have lower costs than MRI.

WILD (1950) was the first who described that A-Mode ultrasound can be used for investigating live fat and muscle tissues of animals. He found that ultrasound is non destructive and humane. The technology continued to progress until today B-Mode (brightness modulation) is a widely used technology for imaging tissue. While A-Mode is onedimensional and is limited to measuring depth of tissue, B-Mode allows characterization of tissue with different densities. Real-time ultrasound is a specialized version of B-Mode ultrasound-producing images almost instantaneously thereby creating »live«, moving objects (GRESHAM 2004). An other specialized version of ultrasound is VOS used mainly in France (TŐZSÉR et al. 2001).

PRICE et al. (1958) was one of the pioneers who used ultrasound on farm animals. The development of the equipments allowed the wide use of real-time ultrasound in the animal production (HOUGHTON \& TURLINGTON 1992).

PFEIFFER et al. (1985) found that ultrasonic measurements could improve the effectiveness of performance testing. They recommended to relate the quotient of ultrasonic fat thickness and ultrasonic muscle thickness to the carcass trait values in further studies.

TÖZSÉR et al. (2003) found that subcutan fat thickness of Red Angus and Angus breed didn't differ from each other.

Many researchers reported that accuracy of ultrasonic measured subcutan fat thickness and REA is quite good (BRETHOUR 1990, DUELLO et al. 1990, SMITH et al. 1992, PERKINS et al. 1992a, PERKINS et al. 1992b, WALDNER et al. 1992, BRETHOUR 1992, ROBINSON 1992, RÖSLER et al. 1996, MAY et al. 2000, GREINER et al. 2003). HARTJEN et al. (1993) investigated a total of 648 young bulls of different breeds just before slaughter. The relationship between the musculus longissimus dorsi area measured by ultrasound and the corresponding measurement on the carcass ranged from $r=0.68$ (1st trial) to $r=0.80$ (2nd trial). 


\section{Material and methods}

Ultrasonic and some slaughter data of 10 Angus, 10 Hungarian Simmental, 10 Limousin and 10 Charolais fattening bulls were investigated. Animals were kept at the same feedlot, under the same conditions. Their diet was corn silage and sugar beet pulp with concentrate with small amount of hay. Animals were slaughtered at nearly the same age in 4 groups. Ultrasonic measurements were taken by the same person with a Falco 100 (Pie Medical) ultrasonic equipment with $18 \mathrm{~cm}$ linear array probe $(3,5 \mathrm{MHz})$ at the feedlot just before slaughtering. Fat thickness was measured at the rump (P8 site): the perpendicular intersection of the line from the third sacral vertebrae with a line from the inside of the pin bone. Ultrasonic REA (UREA) was measured between the 12-13th ribs, near to the spine, parallel to the ribs. Liveweight was measured by digital scale just after taking the ultrasonic measurements, at the feedlot. After slaughter, carcass REA (CREA) was measured, carcass weights were taken and carcasses were judged on the base of EUROP system. The database was processed with ANOVA (LSD test) by breed and analysis of correlation were proceeded by SPSS 9.0 for Windows.

\section{Results and discussion}

Preslaughter and postslaughter results of the animals (average and standard deviation) can be seen in Table 1 and Table 2. There were significant differences between breeds in daily gain during fattening period, moreover slaughter weight, P8, UREA, killing out percentage and CREA. Differences between breeds as for slaughter age were not significant.

Table 1

Preslaughter data of the animals

Mastdaten der Bullen

\begin{tabular}{lccccc}
\hline Average \pm standard deviation & $\begin{array}{c}\text { Liveweight } \\
(\mathrm{kg})\end{array}$ & $\begin{array}{c}\text { Age } \\
(\text { day })\end{array}$ & $\begin{array}{c}\text { Average daily } \\
\text { gain }(\mathrm{kg} / \text { day })\end{array}$ & $\begin{array}{c}\text { UREA } \\
\left(\mathrm{cm}^{2}\right)\end{array}$ & $\begin{array}{c}\text { P8 } \\
(\mathrm{cm})\end{array}$ \\
\hline Angus & $645 \pm 41.5^{\mathrm{a}}$ & $566 \pm 15.8^{\mathrm{a}}$ & $1.36 \pm 0.14^{\mathrm{a}}$ & $102.9 \pm 8.9^{\mathrm{a}, \mathrm{b}}$ & $1.05 \pm 0.28^{\mathrm{a}}$ \\
Hungarian Simmental & $676 \pm 41.8^{\mathrm{a}, \mathrm{b}}$ & $563 \pm 47.4^{\mathrm{a}}$ & $1.30 \pm 0.21^{\mathrm{a}, \mathrm{b}}$ & $102.7 \pm 10.4^{\mathrm{a}}$ & $0.62 \pm 0.13^{\mathrm{b}}$ \\
Limousin & $655 \pm 50.8^{\mathrm{a}, \mathrm{b}}$ & $573 \pm 71.0^{\mathrm{a}}$ & $1.18 \pm 0.11^{\mathrm{b}}$ & $111.2 \pm 9.6^{\mathrm{b}}$ & $0.62 \pm 0.09^{\mathrm{b}}$ \\
Charolais & $694 \pm 42.3^{\mathrm{b}}$ & $606 \pm 45.9^{\mathrm{a}}$ & $1.30 \pm 0,10^{\mathrm{a}, \mathrm{b}}$ & $108.4 \pm 8.3^{\mathrm{a}, \mathrm{b}}$ & $0.61 \pm 0.18^{\mathrm{b}}$ \\
Overall & $668 \pm 46.7$ & $577 \pm 50.2$ & $1.28 \pm 0.15$ & $106.3 \pm 9.7$ & $0.72 \pm 0.26$ \\
\hline
\end{tabular}

${ }_{\mathrm{a}, \mathrm{b}}$ difference is significant at $P<0.05$ level between values containing different letters

Table 2

Postslaughter data of the animals

Schlachtdaten der Bullen

\begin{tabular}{lccccc}
\hline Average \pm standard deviation & $\begin{array}{c}\text { Hot carcass } \\
\text { weight }(\mathrm{kg})\end{array}$ & $\begin{array}{c}\text { Killing out } \\
\text { percentage }\end{array}$ & $\begin{array}{c}\text { CREA } \\
\left(\mathrm{cm}^{2}\right)\end{array}$ & $\begin{array}{c}\text { EUROP fat } \\
\text { (score) }\end{array}$ & $\begin{array}{c}\text { EUROP muscle } \\
\text { (class) }\end{array}$ \\
\hline Angus & $360.5 \pm 18.0^{\mathrm{a}}$ & $57.6 \pm 1.6^{\mathrm{a}}$ & $98.2 \pm 9.4^{\mathrm{a}}$ & $2^{\mathrm{a}}$ & $\mathrm{R}+^{\mathrm{a}}$ \\
Hungarian Simmental & $378.5 \pm 21.8^{\mathrm{a}}$ & $58.3 \pm 1.4^{\mathrm{a}} \mathrm{b}$ & $101.7 \pm 9.7^{\mathrm{a}}$ & $2-^{\mathrm{b}}$ & $\mathrm{R}^{\mathrm{a}}$ \\
Limousin & $378.9 \pm 35.7^{\mathrm{a}}$ & $59.6 \pm 2.0^{\mathrm{b}, \mathrm{c}}$ & $115.7 \pm 12.6^{\mathrm{b}}$ & $1+^{\mathrm{b}}$ & $\mathrm{U}-^{\mathrm{b}}$ \\
Charolais & $405.7 \pm 22.5^{\mathrm{b}}$ & $60.0 \pm 1.0^{\mathrm{c}}$ & $106.4 \pm 9.5^{\mathrm{a}, \mathrm{b}}$ & $1+^{\mathrm{b}}$ & $\mathrm{R}^{\mathrm{a}}$ \\
Overall & $380.9 \pm 29.4$ & $58.9 \pm 1.8$ & $105.5 \pm 12.0$ & $2-$ & $\mathrm{R}+$ \\
\hline
\end{tabular}

${ }_{\mathrm{a}, \mathrm{b}}$ difference is significant at $P<0.05$ level between values containing different letters 
Results of the analysis of correlation can be seen in Table 3. Correlation between ultrasonic and carcass REA at Angus, Hungarian Simmental, Limousin and Charolais bulls was $0.74,0.74,0.94$ and 0.8, respectively. These results are similar (PERKINS et al. 1992a; ROBINSON 1992, GREINER et al. 2003) or a little bit better (SMITH et al. 1992, PERKINS et al. 1992b, MAY et al. 2000) than values mentioned in the Introduction and in Table 4. Correlation between P8 and EUROP fat score was $0.51,0.73,0.56$ and 0.28 at each breed, respectively. Overall correlation between ultrasonic and carcass REA was $0.83(P \leq 0.01)$, and between $P 8$ and EUROP fat score was $0.69(P \leq 0.01)$. Correlation between EUROP fat score and fat thickness is lighter than between ultrasonic and carcass fat thickness reported by other authors can be seen in Table 4 .

Table 3

Correlation between ultrasonic and carcass measured data

Korrelationen zwischen per Ultraschall- und am Schlachtkörper ermittelten Messdaten

\begin{tabular}{lcccc}
\hline & $\begin{array}{c}\text { P8-EUROP } \\
\text { fat score }\end{array}$ & UREA-CREA & $\begin{array}{c}\text { CREA-EUROP } \\
\text { muscle score }\end{array}$ & $\begin{array}{c}\text { UREA-EUROP } \\
\text { muscle score }\end{array}$ \\
\hline Angus & 0.51 & $0.74^{*}$ & -0.28 & $-0.75^{*}$ \\
Hungarian Simmental & $0.73^{*}$ & $0.74^{*}$ & 0.22 & 0.54 \\
Limousin & 0.56 & $0.96^{* *}$ & 0.58 & 0.58 \\
Charolais & 0.28 & $0.80^{* *}$ & 0.14 & -0.13 \\
Overall & $0.69^{* *}$ & $0.83^{* *}$ & $0.44^{* *}$ & 0.25 \\
\hline
\end{tabular}

${ }^{*}$ correlation is significant at $P<0.05$ level ${ }^{* *}$ correlation is significant at $P<0.01$ level

Table 4

Correlation of ultrasonic measured fat thickness and REA to the certain traits measured on slaughtered animals by different authors.

Korrelationen zwischen Ultraschall- und am Schlachtkörper ermittelten Messwerten aus Literaturergebnissen

\begin{tabular}{llcc}
\hline Author & Equipment & Subcutan fat thickness & Ribeye area \\
\hline BRETHOUR 1990 & Aloka 210DX & 0.87 & \\
DUELLO et al. 1990 & Aloka 633 & 0.87 & 0.75 \\
SMITH et al. 1992 & Aloka 210DX & 0.82 & 0.63 \\
PERKINS et al. 1992a & Aloka 210DX & 0.75 & 0.60 \\
PERKINS et al. 1992b & Aloka 500V & $0.86-0.87$ & $0.76-0.82$ \\
WALDNER et al. 1992 & Aloka 210DX & 0.86 & 0.73 \\
BRETHOUR 1992 & Aloka 210DX & 0.92 & \\
ROBINSON 1992 & Aloka 210DX and Aloka 500V & 0.90 & 0.87 \\
MAY et al. 2000 & Aloka 210DX & 0.81 & 0.61 \\
GREINER et al. 2003 & Aloka 500V & 0.89 & 0.86 \\
\hline
\end{tabular}

In conclusion it is obvious from the results of the study that REAcan be estimated quite exactly by in vivo ultrasonic measurements. Correlation between P8 and EUROP fat score is looser than correlation between ribeye measurements. Correlation between ribeye measurements and EUROP muscle score is not so high, mainly not significant. The result mentioned above shows the difficulties of the use of EUROP carcass scoring system. Exact accuracy of ultrasonic fat thickness measurement (comparision to the real fat thickness value) have to be investigated in a later experiment. 


\section{References}

Brethour JR (1990) Relationship of ultrasound speckle to marbling score in cattle. J Anim Sci 68, 2603-13

Brethour JR (1992) The repeatability and accuracy of ultrasound in measuring backfat of cattle. J Anim Sci 70, 1039-44

Duello DA, Rouse GH, Wilson DE (1990) Real time ultrasound as a method to measure ribeye area, subcutaneous fat cover and marbling in beef cattle. J Anim Sci 68, 240

Greiner SP, Rouse GH, Wilson DE, Cundiff LV, Wheeler TL (2003): The relationship between ultrasound measurements and carcass fat thickness and longissimus muscle area in beef cattle. J Anim Sci 81, 676-82

Gresham JD (2004) International study guide. Operator training manual for Aquila and Falco Pie Medical, http://www.esaote-piemedical.com [last accessed 23.08.2006]

Hartjen P, Preisinger R, Ernst E (1993) Prediction of carcass composition of live cattle using ultrasonic measurements and at carcass side using additional traits. Arch Tierz 36, 315-24 [in German]

Houghton PL, Turlington LM (1992) Application of ultrasound for feeding and finishing animals. A review. J Anim Sci 70, 930-41

Kallweit E, Wesemeier HH, Smidt D, Baulain U (1994) Application of magnetic-resonance-measurements in animal research. Arch Tierz 37, 105-20 [in German]

May SG, Mies WL, Edwards JW, Harris JJ, Morgan JB, Garrett RP, Williams FL, Wise JW, Cross HR, Savell JW (2000) Using live estimates and ultrasound measurements to predict beef carcass cutability. J Anim Sci $78,1255-61$

Perkins TL, Green RD, Hamlin KE (1992a) Evaluation of ultrasonic estimates of carcass fat thickness and longissimus muscle area in beef cattle. J Anim Sci 70, 1002-10

Perkins TL, Green RD, Hamlin KE, Shepard HH, Miller MF (1992b) Ultrasonic prediction of carcass merit in beef cattle evaluation of technician effects on ultrasonic estimates of carcass fat thickness and longissimus muscle area. J Anim Sci 70, 2758-65

Pfeiffer H, Leuthold G, Wärnke J, Kairies O (1985) Preliminary results of studies on carcass value recordings in live cattle by means of ultrasound. Arch Tierz 28, 111-20 [in German]

Price JF, Pfost HB, Pearson AM, Hall, CW (1958) Some observations on the use of ultrasonic measurements for determining fatness and leanness in live animals. J Anim Sci 17, 1156

Robinson DL, Mcdonald CA, Hammond K, Turner JW (1992) Live animal measurement of carcass traits by ultrasound assessment and accuracy of sonographers. J Anim Sci 70, 1667-76

Rösler HJ, Lengerken von G, Wicke M, Scheeder MRL, Beisch B (1996) Investigations on the accuracy and the application of ultrasonic measurements for predicting carcass composition on live cattle. Arch Tierz 39, 401-13 [in German]

Scholz AM, Förster M (2006) Accuracy of dual energy x-ray absorptiometry for the determination of the body composition of pigs in vivo. Arch Tierz 49, $462-76$ [in German]

Smith MT, Oltjens JW, Dolezal HG, Gill DR, Behrens BD (1992) Evaluation of ultrasound for prediction of carcass fat thickness and longissimus muscle area in feedlot steers. J Anim Sci 70, 29-37

Tőzsér J, Balázs F, Márton I, Zándoki R (2003) Performance of red and aberdden angus candidate breeding bulls in a herd Hung. J Anim Prod Állattenyésztés és Takarmányozás 52, $39-50$ [in Hungarian]

Tőzsér J, Holló G, Domokos Z (2001) Most up-to-date results of the VOS (velocity of sound) technics in French in the estimation of composition of carcasses. Hung J Anim Prod Állattenyésztés és Takarmányozás 50, 197-204 [in Hungarian]

Waldner DN, Dikeman ME, Schalles RR, Olson WG, Houghtonr PL, Unruh JA, Corah LR (1992) Validation of real-time ultrasound technology for predicting fat thicknesses, longissimus muscle areas, and composition of brangus bulls from 4 months to 2 years of age. J Anim Sci 70, 3044-54

Wild JJ (1950) The use of ultrasonic pulses for the measurement of biological tissues and the detection of tissue density changes. Surgery 27,183

Received 14 January 2008, accepted 8 November 2008.

Corresponding author:

MÁRTON TÖRÖK

email: torok@georgikon.hu or tm@nefty.hu

Georgikon Faculty of Agriculturem, University of Pannonia, Deák Ferenc str. 16, 8360 Keszthely, Hungary 